Volume 3 Nomor 2, Agustus 2018, halaman 131-140

\title{
BAGAIMANAKAH RANCANGAN PEMBELAJARAN MATEMATIKA BERBASIS KEWIRAUSAHAAN (RPM-BK) DALAM MENGEMBANGKAN KARAKTER WIRAUSAHA DAN KETERAMPILAN MATEMATIS?
}

\section{HOW IS THE CONCEPT OF ENTREPRENEURSHIP MATHEMATICS BASED TO DEVELOP ENTREPRENEUR CHARACTERS AND MATHEMATICS SKILL?}

\author{
Sudirman, Rosyadi \\ Universitas Wiralodra, Jln. Ir. H. Juanda Km. 3 Indramayu, sudirman@unwir.ac.id, \\ rosrosyadi@yahoo.co.id
}

\begin{abstract}
ABSTRAK
Tujuan utama Sekolah Menengah Kejuruan adalah untuk mencetak tenaga kerja, baik sebagai pekerja maupun sebagai wirausahawan (entrepreneur). Proses pembelajaran matematika di SMK tidak mengintegrasikan program kewirausahaan yang bisa menumbuhkan karakter kewirausahaan dan keterampilan matematis siswa. Upaya untuk menghasilkan rancangan pembelajaran matematika berbasis kewirausahaan dalam mengembangkan karakter wirausaha dan ketrampilan matematis harus dilakukan. Penelitian ini menggunakan metode Research and Development (R\&D). Tahapan penelitian ini terbagi menjadi dua tahap (1) pendefinisian (define), (2) perencanaan (design). Produk rancangan pembelajaran berbasis kewirausahaan terdiri dari silabus, RPP, bahan ajar dan model pembelajaran. Karakter wirausaha terdiri dari tekun, percaya diri, teliti, sistematis, kreatif dan berani mengambil resiko yang diukur dengan menggunakan angket dan lembar observasi. Berdasarkan hasil penelitian dapat disimpulkan (1) tahap pendefinisian aspek silabus, RPP, bahan ajar dan model pembelajaran masih menggunakan silabus dan RPP dari KTSP belum dimodifikasi berdasarkan program keahlian yang bisa menumbuhkan karakter wirausaha dan ketrampilan matematis tertentu; (2) aspek pendesainan silabus, RPP, bahan ajar dan model pembelajaran telah mengintegrasikan nilai-nilai karakter wirausaha dan menumbuhkan keterampilan matematis siswa SMK materi program linear.
\end{abstract}

Kata Kunci: Pembelajaran Matematika, Kewirausahaan, Karakter Wirausaha, Keterampilan Matematis

\begin{abstract}
The existence of Vocational High School is aimed at producing qualified workers or entrepreneurs. In fact, the implementation of teaching and learning Math does not involve the values of entrepreneurship that is useful to develop students' potential in math as well as entrepreneurship. To cope such kind of problem, it is essential that for those who are in charge to operationalize educational system in order to design particular teaching lesson plan that focuses on internalizing the value of entrepreneurship into teaching and learning Math. As the research design, the present study adopts Research and Development $(R \& D)$ in which it deals with two steps, they are (1) define
\end{abstract}


and (2) design. Furthermore, the product of learning design of entrepreneurship-based comprises syllabus, teaching lesson plan, material, and learning model. To identify the students' entrepreneur characters, it is scaled by the questioners and observation that works on some criteria, such as perseverance, self-confidence, thorough, systematic, creative and risk-taking. This study reveals that (1) in defining the elements of syllabus, teaching lesson plan, material, and learning model still adopted syllabus and teaching lesson plan from the unit level curriculum that is not covered the essence of entrepreneurship and math; (2) the aspect in designing syllabus, teaching lesson plan, material, and learning models has integrated the values of entrepreneurship that develops the students' math ability.

Keywords: Mathematics Learning, Entrepreneurship, Entrepreneurial Character, Mathematical Skills

\section{How to Cite: Sudirman \& Rosyadi. (2018). Bagaimanakah Rancangan Pembelajaran Matematika Berbasis Kewirausahaan (RPM-BK) dalam Mengembangkan Karakter Wirausaha dan Keterampilan Matematis?. Mathline: Jurnal Matematika dan Pendidikan Matematika, Vol.3, No.2, 131-140.}

\section{PENDAHULUAN}

Salah satu indikator kemajuan ekonomi suatu bangsa ditentukan oleh banyaknya wirausahawan. Upaya untuk meningkatkan jumlah wirausahawan telah dilakukan oleh pemerintah melalui Kementrian Pendidikan dan Kebudayaan (Kemendikbud) dengan Program "pendidikan kewirausahaan". Program pendidikan kewirausahaan di sekolah dapat diinternalisasikan dan terintegrasi pada seluruh mata pelajaran dan proses pembelajaran (Kementerian Pendidikan Nasional, 2010).

Berdasarkan hasil observasi di Sekolah Menengah Kejuruan (SMK) di Indramayu disimpulkan proses pembelajaran matematika belum mengintegrasikan program keahlian dan pendidikan kewirausahaan dengan matematika SMK. Proses pembelajaran matematika di SMK seolah-olah terpisah dengan dunia nyata siswa SMK. Padahal menurut Sugiyanti \& Muhtaram (2013) titik tolak pembelajaran hendaknya membuat siswa merasa tertarik dan merasa bahwa hal tersebut nantinya berguna untuk kehidupan mereka di masa depan.

Anyagh \& O'kwu (2010) menyimpulkan pengembangan karakter dan keterampilan kewirausahaan yang terintegrasi dengan pembelajaran matematika mengharuskan metode pembelajaran matematika yang digunakannya berpusat pada siswa dan berbasis masalah. Selain itu menurut Odumosu \& Olusesan (2016) berdasarkan hasil penelitiannya menyimpulkan bahwa kemampuan matematika yang digunakan dalam mengembangkan keterampilan kewirausahaan yakni keterampilan dalam berhitung, keterampilan pemecahan masalah, keterampilan yang berpikir kreatif, keterampilan berpikir inovatif, keterampilan analitis, keterampilan pengambilan keputusan. Sidhu (Uka, 2015) tujuan pembelajaran 
matematika yakni untuk: a) memperoleh dan mengembangkan keterampilan di dalam penggunaan pemahaman matematika; b) memperoleh dan mengembangkan kecepatan, kerapian, akurasi dalam menerapkan matematika; c) belajar dan mengembangkan teknik pemecahan masalah; d) mengembangkan kemampuan untuk memperkirakan, memeriksa dan memverifikasi hasil; e) mengembangkan kemampuan berpikir dengan benar, untuk mengeneralisasi dan menarik kesimpulan; f) mengembangkan keterampilan dalam menggambar, membaca, menafsirkan grafik dan tabel statistik; g) mengembangkan keterampilan dalam mengukur, menimbang dan survei; h) mengembangkan kemampuan untuk menerapkan matematika dalam kehidupan masa depan; i) mengembangkan kebiasaan berpikir sistematis dan penalaran obyektif; j) mengembangkan kepercayaan diri untuk memecahkan matematika atau masalah lainnya; k) menunjukkan orisinalitas dan kreativitas.

Ada karakter yang terbentuk ketika siswa belajar matematika dengan benar. Menurut Uka (2015) karakter tersebut antara lain: ketekunan, percaya diri dan sabar, ingin tahu, teliti, kompeten, berani pengambil risiko, menggunakan akalnya, bertindak secara rasional, optimis, realistis, proses yang sistematis, pekerja keras, keteguhan. Sedangkan keterampilan yang dimiliki oleh siswa ketika dia sudah memperoleh pelajaran matematika secara efesien yakni yakni keterampilan dalam berhitung, keterampilan berpikir kreatif, keterampilan berpikir inovatif dan keterampilanberpikir analitis.

Menurut Hartog et al. (Kremer, et al., 2013) kemampuan matematika merupakan salah satu kemampuan yang harus dimiliki oleh seorang pengusaha selain kemampuan verbal kemampuan teknis dan sosial. Ketika seseorang tidak memiliki kemampuan tersebut, besar kemungkinan bahwa usaha yang akan dirintisnya akan mengalami kegagalan. Oleh karenanya proses dan hasil pembelajaran matematika di SMK pada khususnya haruslah diarahkan untuk mengembangkan karakter dan keterampilan wirausaha. Karakater dan keterampilan wirausaha bisa ditumbuhkan melalui integrasi dengan pembelajaran matematika. Sebagai contoh karakter percaya diri merupakan salah satu karakter yang harus dimiliki oleh seorang wirausahawan. Karakter tersebut juga bisa terbentuk melalui pembelajaran matematika, seperti ketika siswa menghadapi tes matematika maka siswa juga harus percaya diri dalam mengerjakan soal tersebut. Contoh lain keterampilan dalam berhitung yang merupakan keterampilan yang harus dimiliki seorang wirausahawan. Keterampilan berhitung dapat tumbuh ketika pembelajaran di rancang yang menekan kepada latihan-latihan dalam berhitung cepat. 
Berdasarkan pemikiran tersebut maka merancang pembelajaran matematika yang dapat mengembangkan keterampilan wirausaha dan kemampuan matematis menjadi sangat penting dilakukan dalam rangka meningkatkan lulusan-lulusan SMK di Indramayu pada khususnya menjadi seorang wirausahawan yang mampu mengintegrasikan nilai-nilai matematika dan meningkatkan keterampilan matematika.

\section{METODE PENELITIAN}

Penelitian ini menggunakan pendekatan Research and Development dengan berpedoman pada model Thiagarajan, et al. (1974) dengan beberapa modifikasi yaitu: (1) pendefinisian (define), (2) perencanaan (design). Pada tahap perancangan pembelajaran matematika akan di rancangan silabus, RPP, bahan ajar, model pembelajaran dan instrumen untuk mengukur keterampilan wirausaha dan kemampuan matematis. Adapun materi yang akan dirancang pada materi program linear X. Alat pengumpul data yang digunakan yakni catatan lapangan, wawancara, observasi. Data yang diperoleh lapangan, wawancara, observasi di analisis secara kualitatif.

Alur kegiatan penelitian dilaksanakan melalui 2 (dua) tahapan bagian yakni: (1) Tahap Define, pada bagian ini kegitan yang dilakukan yakni: (a) Survai lapangan pada wilayah studi penelitian; (b) Studi pustaka dan dokumen penunjang penelitian; (c) Pengumpulan data lapangan (data eksternal) (d) Mengumpulkan informasi terkait. (2) Tahap Design, pada bagian ini mulai: (a) merencanakan pembuatan silabus; (b) merencanakan pembuatan RPP; (c) merencanakan pembuatan bahan ajar; (d) merencanakan pembuatan instrumen penelitian.

\section{HASIL DAN PEMBAHASAN}

\section{Fase Pendefinisian}

Fase ini dimulai dengan melakukan studi pendahuluan dan mengkaji literatur terkait di Sekolah Menengah Kejuruan (SMK) yang ada di Indramayu pada materi program linear. Data yang diperoleh dari hasil studi pendahuluan di analisis dengan mengkategorikan pada aspek analisis silabus, RPP, bahan ajar, model pembelajaran. 


\section{Silabus}

Tabel 1. Hasil Observasi Aspek Silabus

\begin{tabular}{ccc}
\hline Komponen & SMKN 1 Lelea & SMKN 1 Sindang \\
\hline Kurikulum yang digunakan & KTSP & Kurtilas Revisi \\
Materi Program Linear berada di kelas & X & XI \\
Sudah Spesifik dengan silabus kurtilas revisi & Tidak & Ya \\
Pengembangan Silabus & Terpaku pada & Terpaku pada \\
& silabus umum & silabus umum \\
\hline
\end{tabular}

Hasil tabel diatas di dapat informasi bahwa (1) silabus yang digunakan oleh SMKN 1 Lelea masih menggunakan KTSP, sedangkan SMKN 1 Sindang sendiri sudah menggunakan silabus kurikulum 2013 revisi. Fokus pada materi yang berkaitan dengan wirausaha yaitu program linear, maka informasi yang didapat mengenai materi program linear SMKN 1 Lelea berada di kelas X karena menggunakan KTSP, sedangkan di SMKN 1 Sindang materi program linear berada dikelas XI sesuai dengan silabus kurikulum 2013 revisi. Saat ini sudah diberlakukan kurikulum 2013 untuk setiap satuan pendidikan baik secara bertahap maupun menyeluruh, pada kenyataannya bahwa penggunaan kurikulum 2013 belum menyeluruh dibuktikan dengan hasil survai peneliti yaitu SMKN 1 Lelea belum menggunakan kurikulum 2013revisi khususnya pada mata belajar matematika. Pengembangan silabus sendiri untuk SMKN 1 Lelea dan SMKN 1 Sindang hanya terpaku pada silabus yang sudah ada. Padahal untuk silabus umum dari kementerian pendidikan dan kebudayaan diperuntukan untuk SMA/MA/SMK/MAK sehingga harus disesuaikan dengan sekolah masing-masing baik silabus matematika umum atau silabus matematika khusus keahlian tertentu.

\section{Rencana Pelaksanan Pembelajaran (RPP)}

Tabel 2. Hasil Observasi Aspek RPP

\begin{tabular}{|c|c|c|}
\hline Komponen & SMKN 1 Lelea & SMKN 1 Sindang \\
\hline Kompetensi Keahlian & Teknik & Teknik \\
\hline Materi & Program Linear & Program Linear \\
\hline Pendekatan & Saintifik & - \\
\hline Model Pembelajaran & Poblem based learning & - \\
\hline Metode & $\begin{array}{c}\text { Ceramah, diskusi } \\
\text { kelompok,tanya jawab, dan } \\
\text { penugasan }\end{array}$ & $\begin{array}{c}\text { Tanya-jawab, diskusi kelompok, } \\
\text { presentasi dan penugasan } \\
\text { individu }\end{array}$ \\
\hline Media & LCD, papan tulis & - \\
\hline $\begin{array}{c}\text { Permasalahan yang } \\
\text { diberikan }\end{array}$ & $\begin{array}{l}\text { RPP tidak memuat } \\
\text { permasalahan yang akan } \\
\text { diberikan oleh siswa } \\
\text { berkaitan dengan materi }\end{array}$ & $\begin{array}{l}\text { Persoalan yang diberikan sudah } \\
\text { dikaitkan dengan kehidupan } \\
\text { sehari-hari tetapi belum dikaitkan } \\
\text { dengan kewirausahaan yang } \\
\text { berkaitan dengan keahlian yang } \\
\text { diambil siswa }\end{array}$ \\
\hline
\end{tabular}


Hasil tabel diatas di dapat informasi bahwa RPP yang digunakan SMKN 1 Lelea maupun SMKN 1 Sindang diperuntukan untuk siswa dengan kompetensi keahliahan teknik. Materi yang tercantum pada RPP SMKN 1 Lelea dan SMKN 1 Sindang adalah materi program linear. Pendekatan pembelajaran yang tercantum pada RPP SMKN 1 Lelea yaitu pendekatan saintific, sedangkan RPP SMKN 1 Sindang tidak mencantumkan pendekatan pembelajaran yang digunakan. Model pembelajaran yang tercantum pada RPP SMKN 1 Lelea yaitu model pembelajaran Poblem based learning, sedangkan RPP SMKN 1 Sindang tidak mencantumkan model pembelajaran yang digunakan. Metode pembelajaran yang tercantum pada RPP SMKN 1 Lelea yaitu ceramah, diskusi kelompok, tanya jawab, dan penugasan. Sedangkan metode pembelajaran yang tercantum dalam RPP SMKN 1 Sindang yaitu tanya-jawab, diskusi kelompok, presentasi dan penugasan individu. Media pembelajaran yang tercantum pada RPP SMKN 1 Lelea yaitu LCD, papan tulis. Sedangkan RPP SMKN 1 Sindang tidak mencantumkan media pembelajaran yang digunakan. RPP yang digunakan SMKN 1 Lelea tidak memuat permasalahan yang akan diberikan oleh siswa berkaitan dengan materi. Sedangkan RPP yang digunakan SMKN 1 Sindang memuat permasalahan yang akan diberikan kepada siswa dan permasalahan tersebut sudah dikaitkan dengan kehidupan sehari-hari tetapi belum dikaitkan dengan kewirausahaan yang berkaitan dengan keahlian yang diambil siswa.

\section{Bahan Ajar}

Tabel 3. Hasil Observasi Aspek Bahan Ajar

\begin{tabular}{|c|c|c|}
\hline Komponen & SMKN 1 Lelea & SMKN 1 Sindang \\
\hline Sumber yang digunakan & $\begin{array}{l}\text { Buku siswa matematika XI } \\
\text { diterbitkan Depdikbud }\end{array}$ & $\begin{array}{l}\text { Buku siswa mata pelajaran } \\
\text { matematika jilid XI }\end{array}$ \\
\hline $\begin{array}{l}\text { Kesesuaian sumber belajar } \\
\text { dengan kurikulum }\end{array}$ & Kurang sesuai & Cukup sesuai \\
\hline $\begin{array}{c}\text { Kesesuaian sumber belajar } \\
\text { dengan kejuruan }\end{array}$ & Kurang sesuai & Sudah sesuai \\
\hline $\begin{array}{l}\text { Kesesuaian sumber belajar } \\
\text { dengan keahlian siswa }\end{array}$ & Kurang sesuai & Kurang sesuai \\
\hline
\end{tabular}

Hasil tabel diatas didapat informasi bahwa bahan ajar yang digunakan oleh SMKN 1 Lelea adalah buku siswa matematika XI. Buku sumber yang digunakan ini tidak satupun buku matematika yang dikhususkan untuk sekolah kejuruan, guru SMKN 1 Lelea lebih memilih buku yang diperuntukan sekolah menengah atas dan berbasis KTSP karena menurutnya sumber buku yang digunakan dari mana saja yang penting isinya memuat materi yang ia butuhkan. Sedangkan untuk SMKN 1 Sindang menggunakan bahan ajar yaitu buku siswa mata pelajaran matematika jilid XI. Berbeda dengan SMKN 1 Lelea, 
SMKN 1 Sindang ini sudah menggunakan buku sumber matematika yang diperuntukan untuk sekolah kejuruan berbasis KTSP. Kesesuaian sumber belajar SMKN 1 Lelea dengan kurikulum kurang sesuai karena masih menggunakan buku berbasis KTSP, sedangkan kesesuaian sumber belajar SMKN 1 Sindang cukup sesuai karena buku yang digunakan berbasis kurtilas. Kesesuaian sumber belajar SMKN 1 Lelea dengan kejuruan kurang sesuai karena buku yang digunakan adalah buku yang diperuntukan sekolah menengah atas, sedangkan buku yang digunakan SMKN 1 Sindang sudah sesuai karena menggunakan buku matematika yang diperuntukan sekolah menengah kejuruan. Kesesuaian sumber belajar dengan keahlian siswa untuk SMKN 1 Lelea dan SMKN 1 Sindang kurang sesuai karena kedua sekolah yang telah di survai oleh peneliti ini belum menggunakan buku matematika kejuruan yang diperuntukan sesuai dengan keahlian siswa, misalnya buku matematika SMK bidang keahlian teknik.

\section{Model Pembelajaran}

Tabel 4. Hasil Observasi Aspek Model Pembelajaran

\begin{tabular}{ccc}
\hline Komponen & SMKN 1 Lelea & SMKN 1 Sindang \\
\hline $\begin{array}{c}\text { Model pembelajaran yang digunakan } \\
\text { Masalah yang terkait dengan } \\
\text { kewirausahaan }\end{array}$ & Poblem based learning & Inkuiri Terbimbing \\
\hline
\end{tabular}

Hasil tabel diatas didapat informasi bahwa model pembelajaran yang digunakan oleh SMKN 1 Lelea pada pembelajaran matematika adalah Poblem based learning. Sedangkan model pembelajaran yang digunakan SMKN 1 Sindang pada pembelajaran matematika yaitu inkuiri terbimbing. Tahap pembelajaran pada Poblem based learning ataupun inkuiri terbimbing hanya diberikan permasalahan yang sederhana, sedangkan siswa kejuruan dituntut untuk bisa berwirausaha setelah lulus khususnya keahlian tata busana sehingga dibutuhkan latihan latihan soal matematika yang mendukung keahliannya tersebut serta menjadikan matematika berperan penting pada calon wirausaha. Kedua sekolah ini belum menyajikam masalah atau soal matematika yang berkaitan dengan kewirausahaan

\section{Fase Perancangan}

\section{Rancangan Silabus}

Fase perancangan pada aspek silabus terintegrasi dengan penambahan karakter wirausaha dan langkah-langkah pembelajaran yang digunakan. Karakter wirausaha yang ditumbukan yang tercantum dalam silabus terdiri dari (1). ketekunan; (2) percaya diri; (3) 
138 Bagaimanakah Rancangan Pembelajaran Matematika Berbasis Kewirausahaan (RPM$B K)$ dalam Mengembangkan Karakter Wirausaha dan Keterampilan Matematis?

teliti; (4) proses yang sistematis; (5) kreatif; (6) berani mengambil resiko. Pada aspek silabus digunakan silabus untuk kurikulum 2013 dengan modifikasi tertentu.

\begin{tabular}{|c|c|c|c|c|c|c|c|}
\hline \multicolumn{8}{|c|}{ SILABUS } \\
\hline $\begin{array}{l}\text { Nama Sekolah } \\
\text { Mata Pelajaran } \\
\text { Kelas / Program } \\
\text { Semester } \\
\text { STANDAR KOMPETENS } \\
\text { |t. }\end{array}$ & \multicolumn{2}{|c|}{$\begin{array}{l}\text { : SMK } \\
\text { MATEMATIKA } \\
\text { : XII/ } \\
\vdots \text { GENAP } \\
\text { : } 5 \text {. Menyelesaikan masalah program linear }\end{array}$} & & & & & \\
\hline \multirow{2}{*}{$\begin{array}{c}\text { Kompetensi } \\
\text { Dasar }\end{array}$} & \multirow{2}{*}{$\begin{array}{l}\text { Indikator Ketrampilan } \\
\text { Wirausaha }\end{array}$} & \multirow[b]{2}{*}{ Kegiatan Pembelajaran } & \multirow[b]{2}{*}{ Indikator } & \multicolumn{2}{|c|}{ Penilaian } & \multirow{2}{*}{$\begin{array}{l}\text { Alokasi } \\
\text { Waktu } \\
\text { (TM) }\end{array}$} & \multirow{2}{*}{$\begin{array}{c}\text { Sumber } \\
\text { /Bahan /Alat }\end{array}$} \\
\hline & & & & Teknik & $\begin{array}{c}\text { Bentuk } \\
\text { Instrumen }\end{array}$ & & \\
\hline $\begin{array}{l}5.2 \text { Menentukan } \\
\text { model } \\
\text { matematika dari } \\
\text { soal ceritera } \\
\text { (kalimat verbal) }\end{array}$ & $\begin{array}{l}\text { 1. Tekun } \\
\text { 2. percaya diri } \\
\text { 3. telifi } \\
\text { 4. sistematis } \\
\text { 5. kreatifi } \\
\text { 6. berani mengambil } \\
\text { resiko. }\end{array}$ & 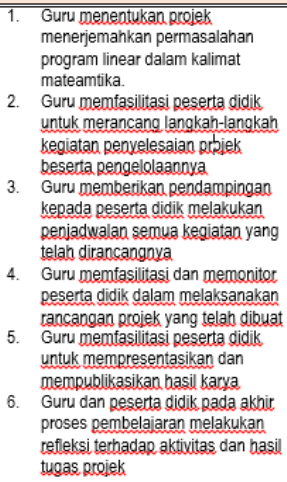 & $\begin{array}{l}\text {-Meneriemabakan seal ceritera } \\
\text { (kalimat verbal) ke dalam kalimat } \\
\text { mattematika } \\
\text {-Menentukan daerah penyelesaian } \\
\text { dari sistem pertidaksamaan linear } \\
\text { yang telah disusun dalam model } \\
\text { matematika }\end{array}$ & $\begin{array}{l}\text { Tugas kelompok } \\
\text { berbasis Project. }\end{array}$ & $\begin{array}{l}\text { Angket, lembar } \\
\text { pengamatan } \\
\text { dan tes Uraian }\end{array}$ & $\frac{10}{6}$ & $\begin{array}{l}\text { Sumber: } \\
\text { Buku } \\
\text { Matematika } \\
\text { Berbasis } \\
\text { Kevirausahaan } \\
\text { Alat: } \\
\text { - Laptop } \\
\text { - LCD } \\
\text { - OHP }\end{array}$ \\
\hline
\end{tabular}

Gambar 1 Rancangan Aspek Silabus

\section{Rancangan RPP}

Pada aspek Rencana Pelaksanaan Pembelajaran (RPP) terdiri dari tujuan pembelajaran, materi pembelajaran, indikator karakter wirausaha, model pembelajaran, langkah-langkah pembelajaran, alat dan sumber belajar dan penilaian. Indikator penilaian dimungkin untuk menilai karakter wirausaha dengan menggunakan angket dan lembar pengamatan sedangkan kemampuan matematis siswa dengan menggunakan tes uraian berbasis masalah.

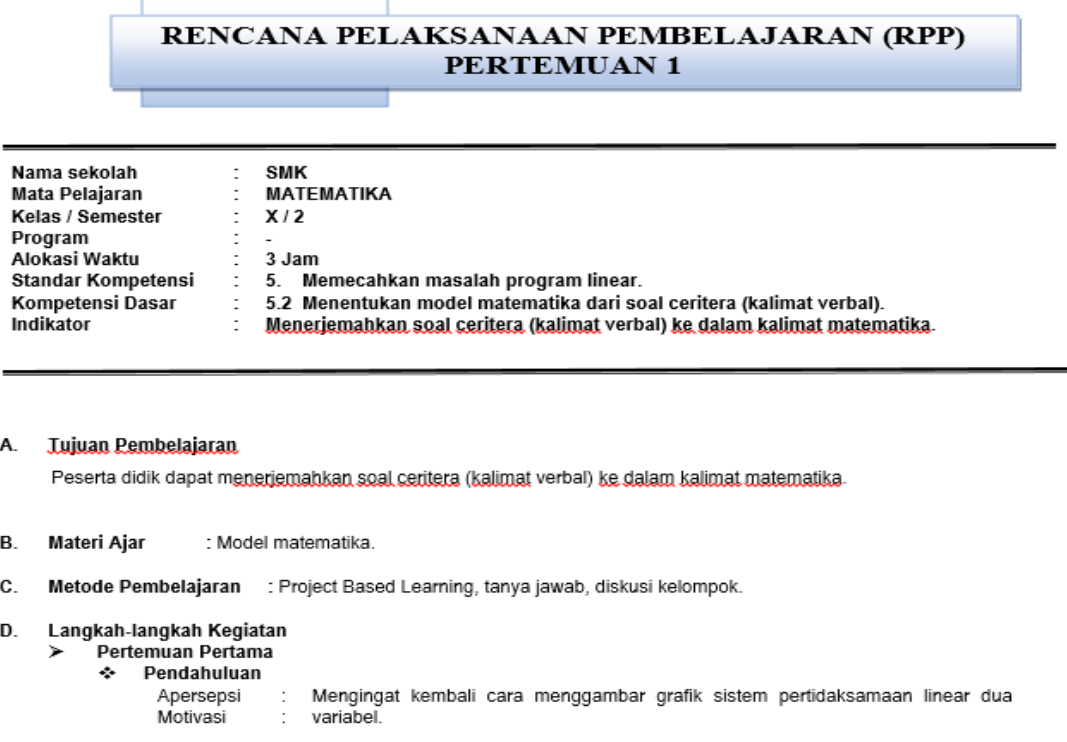

Gambar 2 Rancangan Aspek Silabus 


\section{Rancangan Bahan Ajar}

Pada aspek perancangan bahan ajar, bahan ajar di rancang dengan mengintegrasikan nilai-nilai karakter wirausaha pada materi program linear. Pada materi program linear peserta didik dituntun untuk menyelesaikan sebuah projek usaha yang sudah dirancang oleh guru dan tersirat dalam bahan ajar tersebut. Bahan ajar tersebut juga di rancang sebagai manual prosedur di dalam menyelesaikan projek yang diberikan oleh guru. Guru akan dapat melihat sejauh mana projek tersebut bisa diselesaikan oleh guru sekaligus dapat menilainya berdasarkan bahan ajar tersebut.

\section{Rancangan Model Pembelajaran}

Berdasarkan hasil observasi terhadap kebutuhan model pembelajaran yang dapat meningkatkan ketrampilan wirausaha dan kemampuan matematis siswa yakni menggunakan Projek Based Learning. Rancangan Project Based Learning disusun berdasarkan langkah-langkah praktis yang dapat dilihat dari tabel 5 sebagai berikut:

\section{Tabel 5. Langkah Project Based Learning}

\begin{tabular}{|c|c|c|}
\hline Langkah-Langkah & Kegiatan & Deskripsi \\
\hline Langkah 1 & Penentuan projek dan tugas & $\begin{array}{l}\text { Guru memberikan arahan materi yang } \\
\text { akan dibahas dan menentukan projek } \\
\text { yang akan diselesaikan oleh peserta } \\
\text { didik }\end{array}$ \\
\hline Langkah 2 & $\begin{array}{l}\text { Perancangan langkah- } \\
\text { langkah penyelesaian projek }\end{array}$ & $\begin{array}{l}\text { Guru memfasilitasi peserta didik untuk } \\
\text { merancang langkah-langkah } \\
\text { penyelesaian kegiatan } \\
\text { pengelolaannya }\end{array}$ \\
\hline Langkah 3 & $\begin{array}{l}\text { Penyusunan jadwal } \\
\text { pelaksanaan projek }\end{array}$ & $\begin{array}{l}\text { Guru memberikan pendampingan } \\
\text { kepada peserta didik melakukan } \\
\text { penjadwalan semua kegiatan yang telah } \\
\text { dirancangnya }\end{array}$ \\
\hline Langkah 4 & $\begin{array}{l}\text { Penyelesaian projek dengan } \\
\text { fasilitasi dan monitoring } \\
\text { guru }\end{array}$ & $\begin{array}{l}\text { Guru memfasilitasi dan memonitor } \\
\text { peserta didik dalam melaksanakan } \\
\text { rancangan projek yang telah dibuat }\end{array}$ \\
\hline Langkah 5 & $\begin{array}{l}\text { Penyusunan laporan } \\
\text { presentasi/publikasi } \\
\text { projek }\end{array}$ & $\begin{array}{l}\text { Guru memfasilitasi peserta didik untuk } \\
\text { mempresentasikan } \\
\text { mempublikasikan hasil karya }\end{array}$ \\
\hline Langkah 6 & $\begin{array}{l}\text { Evaluasi proses dan hasil } \\
\text { projek }\end{array}$ & $\begin{array}{l}\text { Guru dan peserta didik pada akhir } \\
\text { proses pembelajaran melakukan refleksi } \\
\text { terhadap aktivitas dan hasil tugas projek }\end{array}$ \\
\hline
\end{tabular}

\section{KESIMPULAN}

Berdasarkan hasil penelitian, dapat disimpulkan (1) Tahap pendefinisian aspek silabus, RPP, bahan ajar dan model pembelajaran yang diperoleh dari hasil observasi dan wawancara di sekolah-sekolah yang ada di Indramayu disimpulkan bahwa (a) silabus dan 
140 Bagaimanakah Rancangan Pembelajaran Matematika Berbasis Kewirausahaan (RPM$B K)$ dalam Mengembangkan Karakter Wirausaha dan Keterampilan Matematis?

RPP yang digunakan masih menggunakan silabus dan RPP dari KTSP belum dimodifikasi berdasarkan program keahlian yang bisa menumbuhkan karakter wirausaha dan ketrampilan matematis tertentu; (b) bahan ajar yang digunakan belum mencirikan bahan ajar yang sesuai dengan program keahlian yang diharapkan dapat menumbuhkan karakter dan ketrampilan matematis siswa; (c) model pembelajaran yang digunakan masih menggunakan model pembelajaran yang tidak menumbuhkan karakter dan ketrampilan matematis siswa. (2) Aspek pendesainan silabus, RPP, bahan ajar dan model pembelajaran telah mengintegrasikan nilai-nilai karakter wirausaha dan menumbuhkan keterampilan matematis siswa SMK materi program linear. Sedangkan saran yang diberikan yakni perlu adanya pengembangan lebih lanjut terkait dengan penelitian ini.

\section{UCAPAN TERIMAKASIH}

Terimkasih kepada semua pihak yang telah membantu penelitian dan penulisan karya ilmiah ini.

\section{DAFTAR PUSTAKA}

Anyagh, P.I \& O'kwu, E.I. 2010. Developing Entrepreneurial Skills through School Mathematics Education. Journal of Teacher Perspective, Vol 4 no. 4, 545-549.

Kementerian Pendidikan Nasional. 2010. Pengembangan Pendidikan Budaya dan Karakter Bangsa. Jakarta: Badan Penelitian dan Pengembangan Pusat Kurikulum Kemendiknas

Kremer M, Robinson J, \& Rostapshova, J. 2013. Success in Entrepreneurship: Doing the Math. (Online). Tersedia: https://people.ucsc.edu/ jmrtwo/doing the math.pdf. [Diunduh 3 Juli 2018].

Uka, N.K. 2015. Developing Entrepreneurial Skills in Secondary School Students through Effective Mathematics Education in Aba, Nigeria. International Journal of Education, Learning and Development, Vol.3, No.7, 1-11.

Odumosu, M.O \& Olusesan, E.G. 2016. Relevance of Mathematics Education to Entrepreneurship Skills Acquisition towards the Realization of Vision 20:2020. International Journal for Cross-Disciplinary Subjects in Education (IJCDSE), Volume 7, Issue 2, 2768- 2773.

Sugiyanti \& Muhtarom. 2013. Merancang Pembelajaran Matematika RealistikYang Mengembangkan Jiwa Kewirausahaan. Prosiding Seminar Pendidikan Matematika Universitas Negeri Surabaya Tahun 2013, 1-11. 